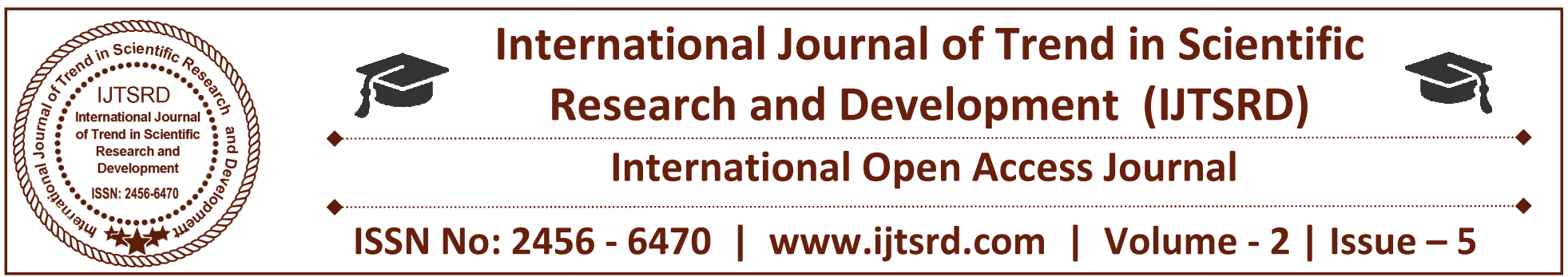

\title{
Entry of women in Sabarimala Temple, A Right or A Right in disguise
}

\author{
V. S. Krishna, N. Parmesh \\ B.B.A., L.L.B. (Hons) \\ Shanmugha Arts, Science, Technology \& Research Academy \\ Deemed University, Thanjavur, Tamil Nadu, India
}

\begin{abstract}
One of the heated argument which we all are well aware in recent times is that the prohibition of the women's entry in Sabarimala Temple. Kerala's Sabarimala Temple is one of the temples which allow all the religions and castes without any discrimination. It is a well-known fact that Sabarimala Temple is the second largest seasonal pilgrimage subsequent to the Islamic Holy Site of Mecca which is situated in Saudi Arabia. Unlike other temples in India, this temple is quite significant about the dress code of its devotees which denotes that the devotees are equal before the Lord Ayyappa. The authors in this research article would like to cite out the historical background of the pilgrimage along with the reasons as to why women aren't allowed inside the temple and also the practicality involved which would substantiate the insightful reasoning for the restriction.
\end{abstract}

Keywords: Sabarimala, restriction, women's entry, religion, historical background.

\section{INTRODUCTION}

Lord Ayyappa is known to be a chronic bachelor (also known as a Naishtika Brahmachari) of the Sabarimala Temple. The Temple has been a shrine for Lord Ayyappan which is located at the Periyar Tiger Reserve in the Western Ghat mountain ranges of Kerala in Pathanamthitta District. Sree Ayyappa was born from the union of Lord Shiva and Lord Vishnu (mythical enchantress Mohini). This union between Lord Shiva and Lord Vishnu are represented as 'Hariharaputra' where Lord Vishnu is recognized as Hari and Lord Shiva is recognized as Hara. The story behind the birth of the legend Lord Ayyappa has to be looked into the prehistoric scriptures or Puranas. As per the Puranas, when Goddess Durga (sister of Lord Vishnu) had killed King Mahishasur, his sister Mahishi wanted to take a revenge on her brother. She was borne with Lord Brahma's boon which not only made her indestructible but also was based on the fact that the only child born from the union of Lord Shiva and Lord Vishnu can only defeat her. For this reason, Lord Vishnu had incarnated into Mohini and wed with Lord Shiva in order to give birth to a child and save the world from annihilation. When Lord Ayyappa had accomplished his destiny by defeating the demon, it was found out that a beautiful woman had emerged from her body asking him to marry her. Lord Ayyappa refuses the women by assuring that he would marry her only when Kanni-swamis (first-time devotees) had stopped coming to the temple during the period of Mandalam i.e., (November - January) and till then he would remain as celibate. In order to find out the kanni-swamis who visit the temple, the first time devotees are made to mark their arrival by prodding a stick at the Sharam kuthi. With the assurance given by Lord Ayyappa, the women is now worshipped as Malikapurathamma (also known as manjamatha) who waits for him at the neighboring shrine near the Sabarimala Temple. Lord Ayyappa's idol was sculpted and installed on the day of Makara Sankranthi by Lord Parasuram.

Reason behind the prohibition of women from entering the Pilgrimage

The Journey towards the Sannidhanam of the Sabarimala Temple has always been a feast for the eyes of the devotees. Lord Ayyappa is known to 
answer the prayers of his devotees who visit his temple with the utmost good faith and follow the pilgrimage ritual. The devotees normally visit the main temple through Periyapadha usually during November - January where the most divine moment falls on January 14th which is to be Makara Sankranti. It has always been a strenuous journey to reach the pilgrimage which covers about 48 miles on foot through dense forest and hill trek. It has never been an easy task to reach the sannidhanam. One has to meet and go through a lot of hurdles in order to reach the destination. It has always been a religious practice to follow the 41-day Mandala Vratham meticulously before going to the temple. The significance behind the Mandala Vratham has been a method to cleanse the thoughts and actions of the devotees before going to the temple.

Apart from the 41-day Mandala Vratham, one must follow some religious practices on their way to the pilgrimage. It has been a practice that the devotees first stop at the Vavar Mosque. Vavar, an Arab commander, is known to be one of the most loyal subjects who was defeated by Lord Ayyappa. The devotees paint their faces and dance during the Madalam period which depicts the joyfulness of the people for defeating Mahishi. This event Erumeli Pettatullal has always been a spectacular one where the essence of the practice is to let go of one's ego and surrender to Lord Ayyappa.

The devotees must various temples before they reach the Sannidhanam. After the devotees reach the Pampa River which is as holy as the River Ganges, they must take bath in the river which purifies the sins of the devotees. Here, the devotees must visit the Sri Kannimoola Ganapathi Temple where, one can find the shrines of Ganapathy, Rama, Anjaneyar, and Naagar and complete the rituals which is to be followed. One must lay their footsteps on the eighteen divine steps before entering the Sanctum Sanctorum. These 18 steps are known as Pathinettapadi. Each step has its own significance where one cannot forego.

\section{Mythological Tradition}

The reason behind the restriction/prohibition of entry of women to Sabarimala Temple is as follows:-

$>$ Firstly, Lord Ayyappa is and has always been a celibate till date and the main reason behind his celibacy is the assurance which was given to Malikapurathamma i.e., till the day he finds out that kanni-swamis stop coming to his temple he would remain a celibate. In order to support this statement, the authors would like to state that this practice has been followed for years and if by any chance the kanni-swamis have ceased to come to the devasthanam during the Mandalam period then it would be considered that the prohibition of the women entry to the pilgrimage would come to an end. It is believed that Lord Ayyappa would get married to Malikapurathamma after the aforesaid period which would be an auspicious day for all the devotees.

Secondly, Entry of women would affect the sanctity of principles of Brahmachariyam. There has always been a religious practice in the Hindu Religion which is based on 4 Ashramas wherein every single person goes through these phases during their lifetime. Lord Ayyappa is going through the first phase of the Ashrama i.e., Brahmacharya. The significance of being a Brahmacharya is to attain both spiritual and practical excellence wherein one must wholeheartedly follow the principle of celibacy. Lord Ayyappa who is a Naishtika Brahmachari is shielding the devotees who visit the Temple and also brings about a change in the vicious thoughts of the humanity. The logic behind the prohibition of entry of women is that it would not only affect the sanctity of the devasthanam but also affect the essential principle of being a Brahmachari.

Lastly, The reason behind the restriction for entry of women aging between 10 - 50 was due to the menstruation cycle which each and every woman would undergo after attaining puberty. The significance of this restriction is in furtherance of the assurance given to Malikapurathamma by Lord Ayyappa as a condition to marry her. It is believed that every woman of age below 10 and above 50 are allowed to enter the sannidhanam. The Travancore Devaswom Board has made it mandatory for every woman to carry an age proof with a view to put an end to the instances of women entering the temple by defying the restriction. Furthermore, Even the restricted women who have removed their uterus are allowed to enter the temple without any restriction provided they bring the medical certificate which states the same.

It is important to understand the relevancy of this matter at this point of time. The Constitutional Bench 
lead by the Chief Justice of India, Dipak Misra JJ., have started hearing the matter concerning prohibition of Women's entry inside the precincts of The Sabarimala Temple.

Chief Justice of India, Dipak Misra: "Where a man can enter, even a woman can go. What applies to a man, applies to a woman."

The authors of this research article aren't conceding to the statement made by the Honourable Chief Justice of India amidst the hearing concerning the Sabarimala Issue. To advance with the aforementioned proposition, the authors have dealt in with the legal dimension of this issue in detail.

The inclination of the law towards the legality of the Ban.

The restriction imposed over the woman to enter into the temple is an "Essential Religious Practice" of this Religious Institution. The classification done on the basis of physiological characteristics between the Women and Men is backed up by strong reasoning and thus is not violative of Article 14 of the Constitution of India. It is, in turn, satisfying the conditions of Intelligible Differentia and Rationale Nexus principle. Sabarimala Temple has a separate denomination for itself as it satisfies all the requirements and it is empowered to manage its own religious affairs. The petition claiming for annulment of the ban over the entry of woman is a lucid paradigm of motivated and vexatious litigation. It is not the original dissenting voice of the women who are connected with this issue. In fact, there is no dissenting voice against this issue itself when we consider the actual voices of those women who understand their rights and limitations with respect to their entry at the premises. It is a foul game played by the public activists owing to their nonchalant and recalcitrant consideration for age-old religious Acharas, Customs, and Practices.

The Proposition enunciated by the Supreme Court in the case of Mahendran v. Secretary, Travancore Devaswom Board ${ }^{2}$ is Unambiguous and Unequivocal

It is very important to consider the judgment of the

\footnotetext{
${ }^{1}$ https://blog.scconline.com/post/2018/07/18/sabarimala-templeban-on-women-entry-where-a-man-can-enter-even- a-womencan-go-sc/

${ }^{2}$ AIR 1993 Ker 42
}

Honourable Supreme Court in the above-mentioned case to understand the legal implications of the ban and the acumen behind such reasoning. Public interest litigation was filed against Former Devaswom Commissioner Smt. Chandrika who conducted rice feeding ceremony of her grand-daughter with other relatives of her, inside the premises of the temple. The photograph of which appeared in a journal by name Jan Bhoomi Daily. The court considering the evidences held that the ban was applicable only in respect of women in a particular group and not women as a class itself. Thus it is a reasonable classification not amounting to class legislation. Class legislation is a piece of law which vests certain rights or advantages to a group of individuals, without conferring the same right to the other members of the group who cannot be differentiated from those to whom the rights are conferred. In the present case, the evidence adduced on behalf of the Devaswom board in the latter part of the article would substantiate the classification.

A gripping scrimmage between Article 25 and Article 26 of the Indian Constitution

A religious Denomination is identified by its customs, practices, tenets, and doctrines. The members of such denomination have the right to secure the sustainment of its Denomination under article 25 of the constitution by the bond of adherence to the holy and sacred principles. This makes every denomination unique from other such institutions making it recondite and in frangible. Article 26 of the constitution throws light on the denominational rights of a Religious Institution. It elucidates that such a denomination would have complete authority to follow its own rites and rituals which it considers as an essential part of its worship.

\section{The Sabarimala Temple qualifies to be a Denomination by itself}

Supreme Court in the case of S. P Mittal v. Union of India $^{3}$ held that for any religious institution to recognize itself as a Denomination under Article 26 has to satisfy three simple conditions. Firstly, the institution should be a collection of individuals who must adhere to a framework of beliefs which are conducive to their spiritual wellbeing. Secondly, they should recognize themselves as a part of a common organization distinctively from other similar groups.

\footnotetext{
${ }^{3}$ AIR 1983 SC 1
} 
Thirdly, they should be designated by a distinctive name.

A reference to the case of Bramchari Sidheswar Sahai v. State of West Bengal ${ }^{4}$ would be of great help to understand the applicability of the above-mentioned conditions. This was a case relating to followers of Ramakrishna. They had a definite set of beliefs conducive which defined their organization. They were collectively referred to as Rama Krishna Matt or Rama Krishna Mission. Similarly, to the question whether Sabarimala is a denomination, the institution satisfies the conditions to recognize itself as a denomination.

The Supreme Court while interpreting this Right of a religious denomination in the case of D. R. R Varu v. State of Andhra Pradesh has explicitly noted that only the denomination should have the autonomy to manage its religious affairs and infringement of which would lead to violation of the right under Article 26(d) of the Constitution of India. Perusal of the case H. R. \& C. E., Madras v. Sree Lakshmindra Thirtha Swamiar of Sri Shiruru Mutt ${ }^{5}$, the court elaborated on the fact that a religion may not only prescribe the ethical conduct for worship but also can prescribe other rituals, modes of worship and observances for the people seeking entry into the place of worship. In simple terms, a religion doesn't exist based on its doctrinal principles and beliefs alone but includes also the practice part of it. Moreover, both are mutually dependent on each other. In Hindu theology, a religion or a religious denomination doesn't exist on the basis of 'Gnana' alone but also on 'Bhakti' and 'Karma Kandas' associated with it'. Through this, it becomes clear that if the restriction of a woman is based on some religious backing, it doesn't suffer from any illegality.

The Supreme Court in a plethora of cases have interpreted the scope of article 26(b) and had held that the religious denomination would have Complete Autonomy over the decisions taken by it subject to the restrictions of Morality, Health and Public Order alone under the Constitution. While Article 25 of the Constitution which empowers a person with Freedom of Conscience and the Right to profess, practice and propagate religion is subject to freedom to manage religious affairs guaranteed under Article 26(b) of the

\footnotetext{
${ }^{4}$ (1995) 4 SCC 646;

${ }^{5}$ AIR 1954 SC 282

${ }^{6}$ Venkataramana Devaru v. State of Mysore AIR 1958 SC 255
}

Constitution and other articles included in Part III of the Constitution.

\section{The evidence adduced on behalf of the Devaswom Board justifying the Restriction}

Whether a practice can be considered as an integral part of the religion should be decided on the basis of the evidence adduced by the parties associated with it. Only those who are closely acquainted with the history of the temple and the knowledge regarding the rituals would be at a position to comment over this issue. The Court called upon the present thanthri of Sabarimala Temple, Sri Neelakandaru, who was in a position to authoritatively provide information concerning the usages followed in the temple. Other Thanthrimukyas were also called to cast their opinion over the issue. Thus the authoritative information provided by the Thanthrimukyas would be the only valuable piece of evidence available to decide the legality of the ban.

The present Thanthri (Chief Priest) had stated that it was his paternal uncle who reinstalled the present diety (idol) in 1950. He added that he conducted the First Pooja after Installation as per the directions of his paternal uncle. The main reason for adhering to the old customs and principles is for the welfare of the temple. For the same reason, the entry was authorized only to those who had strictly adhered to the 41-day penance. Till the integration of Travancore and Cochin took place, the decisive role was played by the members of the Pandalam Palace. The ornaments to be adorned by the idol during the auspicious day of Makaravilaku were placed at the Pandalam Palace. A male member of the family had to take the ornaments in a procession. Myriad of times, suggestions were brought by the president of the board for alteration of age-old customs such as carrying the idol jewel in the van instead by a procession and also for entry of woman aging between 10-50. The suggestions were ostracized and condemned through a press release apprehending that if the usages are violated, the palace members would be afflicted with the curse of the God.

When the Thanthrimukyas aren't able to resolve the ambiguity regarding certain issues, they used to opt for a religious procedure by name Devaprasanam. This is done to know the wishes of a deity whenever such situation arose. This is a procedure followed since time immemorial. In 1985, when Sri Maheswararu was the chief Priest, he conducted 
Devaprasanam to acknowledge the deity's wish over the issue of Entry of Women raised by the then State Secretary of Hindu Munnani. He informed the State Secretary that allowing women between the age group 12- 50 will be contrary to the recondite customs of the temple. The result was one and the same when Devaprasanam was conducted by various other renowned Astrologers. The Devaprasanam report of the Thanthri was exhibited as the record of the Court and authenticity of the document was never in question. The relevant portion of the English translation of the report reads as follows "It is seen that the deity does not like young ladies entering the precincts of the temple". Thus there cannot any other parallel opinion regarding the entry of woman at the premises of Sabarimala.

Lord Ayyappa is a Naisthika Brahmachari according to the Thanthri of the temple. A Naisthika Brahmachari is one who lives adhering completely to the principles of celibacy without any carnal desire in mind, word and deed, still being an epitome of love and attachment for everyone. Owing to this, women devotees are restricted for offering their worship to ensure that the supreme holiness of this adornment is protected without even slightest deviation. This being the most sacred adornment for the deity, the devotees of the Lord Ayyappa are vested with the prime responsibility of protecting his sanctity and asceticism. The Deity at Sabarimala is in the form of Brahmachari whereas the deities present at other Sastha temples (Totally seven) at Achankovil, Aryankavu and Kulathupuzla aren't Brahmacharis. This reasons out why women aren't allowed in Sabarimala Temple alone.

The practice concerning with the restriction of certain category of people as per the scriptures isn't a new issue. Shiva temple in Teliparambu in Eaunur District is one amongst the other temples which forbids the entry of women during the day time until Athazhappja (last pooja for the day) is over. This is based on the belief that Lord Shiva would be sitting with Goddess Parvathy at this time in good mood to shower blessings on his devotees. So beliefs which are an essential part of the practice play a great role in defining the religion itself. In the same way, when Thanthrimukhyas and the other renowned astrologers have acknowledged the wish of the diety regarding the worship by women devotees, it is ought to be revered and it is above all speculations.

In addition to all these, the authors would like to quote the statement given by Honourable Chief Justice of India Dipak Misra during the hearing that "There is no principle of private temple in the country. Temple is not a private property, it is a public property".

Here, the authors would like to affirm the statement given by CJI and also would like to state that the Sabarimala Temple has always been a public property and there is no doubt about it. But there are certain religious practices which have been followed by the devotees of the temple and which cannot be changed. These religious practices have to be respected. It is to be noted that one cannot create any religious practices as it is something which is believed to be true and has become a custom. Custom cannot be taken for granted and it cannot be changed according to the whims and fancies of the people.

\section{Conclusion:}

The authors would like to conclude that the prohibition of entry of women is legal, based on the "Essential Legal Practices" which are being followed from time immemorial. Intense Religious sentiments are deeply rooted in this issue and any kind of indignity would lead to shutting down of the entire temple itself. Such religious beliefs may not necessarily have scientific reasoning but are entwined with the unfathomable and irrefutable faith of millions. Article 26 of the Constitution of India gives a religious denomination, a right to lay down practices and customs for sustainment of spiritual wellbeing. Judicial Intervention with this deeply grounded right of the Denomination would lead to communal disharmony. The authors assert that the restrictions imposed do not suffer from any illegality and thus entitled to be upheld by the Honourable Supreme Court. 